\title{
The Influence of Retailer Enterprise Marketing Information System on Bullwhip Effect
}

\author{
Raed Salah Algharabat ${ }^{1}$, Ahmad M.A. Zamil ${ }^{2}$ \& T. G. K. Vasista $^{3}$ \\ ${ }^{1}$ Department of Marketing, School of Business, The University of Jordan, Amman, Jordan \\ ${ }^{2}$ Department of Marketing, Faculty of Business, Middle East University, Amman, Jordan \\ ${ }^{3}$ Vice-Rector Office for Business Development, King Saud University, Saudi Arab \\ Correspondence: Raed Salah Algharabat, Department of Marketing, School of Business, The University of \\ Jordan, Amman, 11192, Jordan. E-mail: r.gharabat@ju.edu.jo
}

Received: December 17, 2014

Accepted: January 22, 2015 Online Published: February 27, 2015

doi:10.5539/ijbm.v10n3p237

URL: http://dx.doi.org/10.5539/ijbm.v10n3p237

\begin{abstract}
This study aims to investigate the influence of utilizing enterprise level marketing information system in the form of adopting a combination of software tools on the reduction of bullwhip effect. In order to formulate our research hypothesis, we revised the literature extensively. The empirical study findings indicated a positive influence and relationship between the Enterprise Marketing Information System in the form of ERP software, Social Media Monitoring Tools, Business Intelligence Tools and Reduction in Bullwhip Effect.
\end{abstract}

Keywords: business intelligence, enterprise marketing system, ERP, social media monitoring, reducing bullwhip effect

\section{Introduction}

As the 21 st century dawns, the battle for customers have never been so intense that deregulation, diversification and globalization have stimulated a dramatic rise in competition (Algharabat \& Zamil, 2013). Companies are forced to switch from product-centric approach to a customer-centric approach.

Marketing initiatives have a considerable impact on supply chain management (Lummus, Leslie, \& Vokurka, 2003). Marketing mediation involves matching supply to demand, so effective market mediation requires accurate and timely information about the dynamics of supply and demand and incorporates IT-enabled processes, including collaborative planning and forecasting replenishment (CPFR), advanced supply chain planning and logistics and distribution management. Information sharing and collaborative forecasting can mitigate the impact of demand variability on operations and reduce the upstream escalation (Lee et al., 1997).

Leading firms after gradually adopting the product, sales and marketing philosophies, are now facing with new challenges of being customer-centric. The interest for the vendors-customer relationship through relationship marketing has been evolving. Through this relationship orientation, companies are trying to build trustworthy relationship with customers for achieving competitive advantage by accumulating and analyzing customer-focused information (Parvatiyar \& Seth, 2001). Furthermore, Customer Relationship Management $(\mathrm{CRM})$ in terms of sales force automation and marketing automation is poised for revolutionary changes in its organizational context as well as in its relationship with customers (Achrol \& Kotler, 1999). Companies need to assess the business situation and understand the real requirements for automation. In addition to supporting the customer order fulfilment processes, the information capture and its management within CRM applications are playing vital role through the integration of CRM with Enterprise Resource Planning (ERP) and Supply Chain Management (SCM) to enhance customer service (Xu, Yen, \& Lin, 2002).

Implementing ERP, CRM and SCM based enterprise systems can show significant impact on corporate performance (Hendricks, Singhal, \& Stratman, 2007). For example, co-creation of value (about joint creation of value by the company and the customer) fundamentally challenges the traditional distinction between supply and demand. It often creates an experience which consumers can have an active dialogue and co-construct personalized experiences. It is not only giving focus on the demand-site innovation for new products and services, but also innovating new experience for co-creation of value. It is an innovative environment where demand and supply are emergent and contextual. Supply will be associated with facilitating a unique consumer 
experience on demand (Prahlad \& Ramaswamy, 2004).

Contemporary Enterprise Marketing Information Systems involve Web 2.0 based applications where retailers can look for the opportunities to unleash the power of the Social Media Monitoring (SMM) as a new marketing channel to promote their products and services. In particular, the web has created opportunities for electronic word of mouth communication through online discussion forums, electronic bulletin board systems, new groups, blogs, review sites and social networking sites (Cheung, Lee, \& Rabjohn, 2008). Therefore, if companies want to unlock the potential of social media to reinvent their customer relationships, they need to think about CRM in a new light while building and adopting Social CRM strategies (Barid \& Parasnis, 2011).

Even there is mixed evidence about the aggregate prevalence of the bullwhip effects and its consequences (Cacheon et al., 2007), we noticed that investigating the impact of marketing information system as a part of demand management to provide demand certainty from enterprise perspective especially to mitigate the bullwhip effect is very limited in the Arab region (e.g., Al-Shaikh, 2010; Ismail, 2011). Thus, our research study aims to investigate empirically the influence of enterprise information system on providing information sharing in the form of utilizing state-of-the-art information technology based enterprise software tools such as using ERP Software, Social Media Monitoring tools, Business Intelligence Tools and corresponding in reducing the Bullwhip Effect.

\section{The Bullwhip Effect}

The bullwhip effect (Forrester 1961; Lee et al., 1997) has been studied extensively because of its ability to explain the situation of inventory in supply chain. Bullwhip Effect involves risk to manufacturers since it is concerned with the amplification in order-size variance for upstream node in a supply chain (Lee et al., 1997). Demand variability increases from downstream to upstream in a supply chain (Sharma, Balan, Vrat, \& Kumar 2006). At the macro level, Bullwhip Effect induces inefficiencies in production, scheduling (capacity utilization), sourcing, distribution, revenue generation and its realization. At the operating level, it generates more inventories and keeps it in the most inappropriate place, to meet a specified service level. At the performance level it can reduce the velocity of cash, destroy potential revenue by price discounts. It can potentially dilute a competitive (strategy) and position (Ravichandran, 2003). It indicates higher inventories at the upstream and downstream of the supply chain as a result of deficient information sharing, insufficient market data and deficient forecasting capability (Svensson, 2003).

\subsection{Strategies for Mitigating Bullwhip Effect}

The management of multiple relationships across the supply chain is often referred to as SCM. SCM addresses the supply chain from the point of origin to the point of consumption. SCM requires cooperation and coordination between companies' activities and resources in a supply chain. While SCM helps in mitigating the bullwhip effect, implementing SCM strategies such as; demand forecasting with vendor managed inventory and continuous replenishment programs, order batching, point of sale data, electronic data interchange and reduction in price fluctuations effect through offering every day low price (Moyux, Chaib-draa, \& D'Amours, 2006) are essential for companies wishing to reduce the costs associated with the bullwhip effect. Therefore, there are three possible remedies which companies often follow up to mitigate the bullwhip effect. (i) Information sharing i.e. demand information at a downstream site is transmitted upstream in a timely fashion. (ii) Channel alignment i.e. the coordination of pricing, transportation, inventory planning and ownership between the upstream and downstream sites in a supply chain. (iii) Operational efficiency i.e. the activities that improve performance such as reduced costs and lead-time (Lee, Padmanabhan, \& Whang, 1997).

Demand information aggregation is considered one of the important strategies for reducing the bullwhip effect. It means gathering or generating information regarding all demands and orders for a specific supply chain at the required level of detail (Fransoo \& Wouters, 1996) and sharing this information across the supply chain. The information aggregation has the following influences in supply chains and markets (Glazer, 1991):

The greater the information intensity of a firm;

(i) The shorter are its product life cycles;

(ii) The more the traditional product-market boundaries;

(iii) The more tendency moving towards market or customer knowledge as opposed to product knowledge;

(iv) The more the buyer purchasing power; 
(v) The more the reliance on flexible marketing systems so that a greater degree of managerial discretion about the nonproduct elements of the marketing mix, about marketing communication activities such as distribution, advertiser, sales force can become value addition.

(vi) better competitive position and better market-share leadership with differentiation;

(vii) longer Term Market share and shorter term profitability;

(viii) greater possibility of maximizing the number of transaction with the same loyal customer;

(ix) increased strategic alliances;

(x) Better cooperation strategies;

(xi) Promoting agile manufacturing trends by allowing the customer to participate in the product design;

(xii) Greater involvement of marketing department with activities of other functional areas;

(xiii) Allows more reliance on decision making considering both external and internal factors as well as tangible and intangible factors lies with business along the supply chain.

The information aggregation influences the supply chain in terms of cost, quality, delivery speed and agility by assembling organizational resources in response to market opportunities making the enterprise seamless and extendable. Each extended enterprise member contributes to the collective enterprise by sharing facilities, resources, technology and know-how. Transactions within the extended enterprise represent a balance between market and hierarchies. It brings changes in the organization of productive resources, in the relationships between traditional competitors and in the governance of transaction with stimulated new thinking about inter-organizational information flows and the nature of competitive cooperation. The interdependent destinies of allied companies of the collective enterprise reflect the new environment in which supply chain compete against supply chain, and in which traditional competitors increasingly find themselves mutually beneficial collaborators (Greis \& Kasarada 1997). The impact of information sharing on the bullwhip effect has been discussed by many authors (Lee et al, 2000; Moinzadesh, 2002; Moyaux, Chaib-draam, \& D'Amours, 2006; Agarwal et al., 2009, Hussain \& Drake, 2011).

\section{Research Model and Hypotheses}

Figure 1 shows the research model and the hypothesized relationships among its variables which are all developed based on relevant literature. As shown in Figure 1, the model consists of four interrelated latent variables: core ERP software tools, SMM software tools, Business Intelligence Software tools and Reduction in bullwhip effect, where Reduction of bullwhip effect is a dependent variable depending on three independent variables: Use of ERP Software, Use of SMM Software and the Use of Business Intelligence Software Tools.

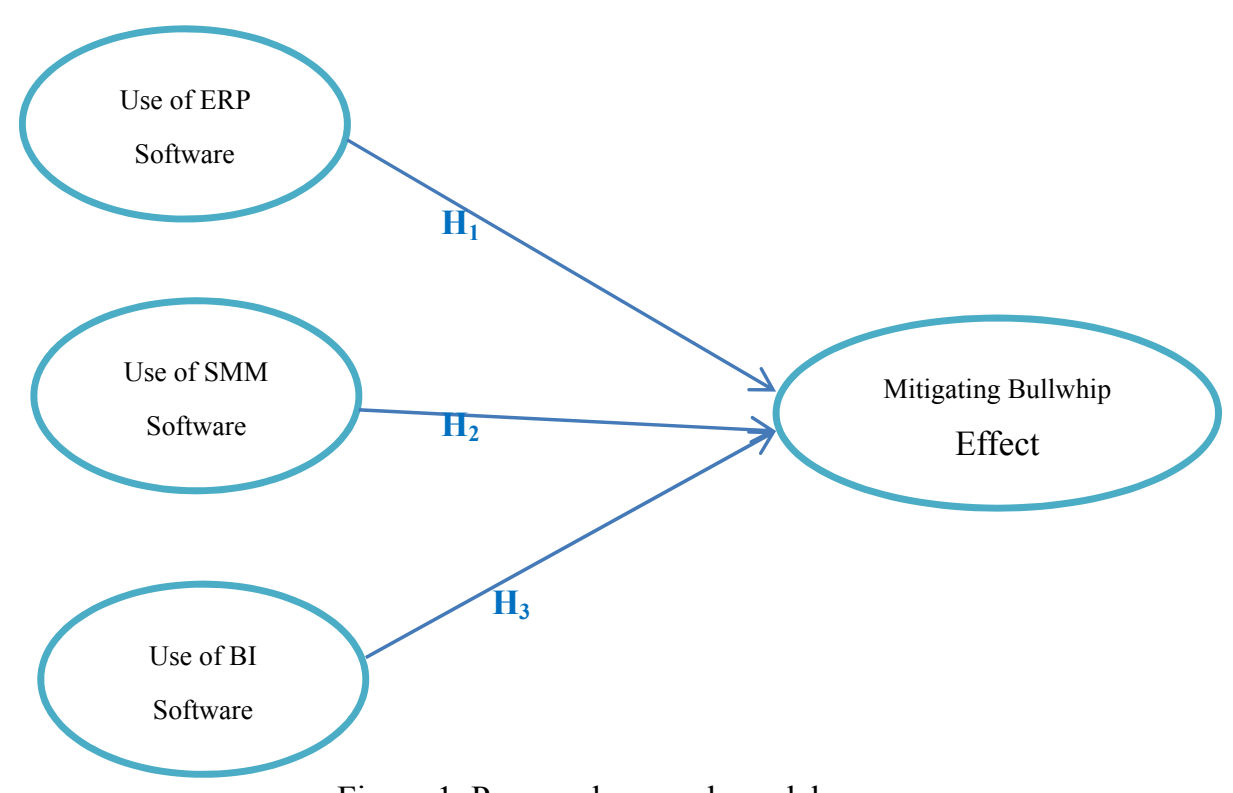

Figure 1. Proposed research model 


\subsection{Influence of ERP on Mitigating Bullwhip Effect}

ERP is a strategy where all levels of the supply chain have visibility to final demand (Torres \& Maltz, 2010). The multiuser ERP system helps to reduce bullwhip effect (Badilo-Pina, 2012). Use of ERP as an IT tool often helps to mitigate the bullwhip effect resulting from information distortion to upstream firms of supply chain (Lai, Xu, \& Zhu, 2010, p. 59). A case study approach (Ravichandran, 2006) of investigating the influence of ERP implementation shows that the use of ERP software has a positive influence in mitigating the bullwhip effect. Information delays can be removed with the use of ERP systems (Burns \& Janamanchi, 2006). Advanced resource planning as a module of extended ERP, improves supply chain effectiveness and helps to mitigate one of the primary sources of the bullwhip effect (Nieuwenhuyse et al., 2011).

Elragal and Al-Serafi (2011) investigate the relationships between ERP and business performance. The authors find that the ERP has reduces the amount of inventory. Further Tsai (2011) asserts that ERP influences corporate performance as such inventory levels are expected to decrease. Mandal \& Gunasekaran (2002) posit that using bar-coding technique also improves the inventory reduction. Information sharing of inventory reduction can influence in mitigating bullwhip effect (Lee, Padmanabhan, \& Whang, 1997; Lee, So, \& Tang, 2000).

ERP software usage with techniques such as vendor managed inventory, just-in-time purchase, SCM software can considerably influence reducing the time and information delays which as a result mitigate the bullwhip effect (McCullen \& Towill, 2002; Disney \& Towill, 2003a; Disney \& Towill, 2003b; Ravichandran, 2008). Furthermore, ERP helps in improving order management and cycle times (Kelle \& Akbulut, 2005; Ravichandran 2008; Tarantilis, Kiranoudis, \& Theodorakopoulos, 2008) and it can reduce procurement costs (Baudmann, Ahsen, \& Diaz, 2004). Thus,

H1: There is a significant positive contributory relationship between using the ERP software and reduction in Bullwhip Effect in Supply Chain.

\subsection{Influence of SMM on Mitigating Bullwhip Effect}

SMM tools are becoming essential to measure social media performance, business impact and return on investment. SMM tools allow businesses to monitor the information related to; business, product competition, key words, phrases and results categorized by the type of social medium such as tweet, blog, post, forum, news item, video or image, eWord-of-Mouth, real time update of information through e-mail alerts and Really Simple Syndication (AlSudairi, Vasista, Zamil, \& Algharabat, 2012). Further AlSudairi et al. (2012) show that eWoM, CRM tools, Web 2.0 tools and Business Intelligence tools can contribute to information sharing and contributes in mitigating bullwhip effect uniquely in its own way.

Though digital actions can positively influence e-business value creation in terms of increasing sales, consumers will migrate to being more active participants and creators of content as social media increasingly becomes the backbone of digital experience. Social Media actions could generate nearly 2.5 times more conversations per 100 consumers than digital actions (Bihr, 2010). The new trends enabled by state-of-the-art information and communication technology are transforming and streamlining supply chain information management. For example, SCIM 2.0 which stands for effective supply chain information management in supply networks using Enterprise 2.0 can have a potential to include semantic representation techniques and applying it to members of a whole supply chain network. The primary objective of Enterprise 2.0 is the support of internal and external information and communication processes and to ensure that relevant information is available through the use of Web 2.0 technologies to stem the bullwhip effect (Auinger \& Nedbal, 2009). Social capital is also identified as influence, control and power. Strong social norms provide increased solidarity among industry groups.

IDG Research services along with the partnership of Kemp Goldberg has conducted an online survey in USA on finding the influence of Social CRM on the supply chain among the business decision-makers with involvement in or responsibility for supply chain operations. The survey concluded the following: (i) current adoption of social media for use in the supply chain is relatively low and is more often used as a method of community participation as opposed to replacing or augmenting traditional CRM activities. (ii) While current adoption is low there is interest at organizations not currently using social media in their supply chain relationships to do so. One key inhibitor to adoption is the willingness and ability of supply chain vendors to engage their customers via social channels. (iii) Among both current and future users, opportunities to engage seem to be focused primarily on mainstream services as well as private communities, vendor wikis and blogs. (iv) This suggests that vendors may start by creating a corporate presence on Facebook Twitter Linkedln and perhaps targeted user communities as a place to start the conversation with their customers. It reveals that respondents want to stay on top of the industry trends but also want to gather specific vendor-related intelligence whether that is pricing, product specs, shipment status etc. Respondents want social media to be a tool for managing vendor relations but also tools that 
can help inform purchase decisions and to engage in dialogue with vendor/experts. (v) Respondents that are utilizing social media in the supply chain provide evidence that they are deriving business value from doing so. However in order for near-term adoption to really grow vendors must educate the market on the benefits of social media in the supply chain, increase the visibility of their social presence and assure privacy, confidentiality and security concerns.

Social Media engagement strategy can be achieved by developing and implementing an integrated and coordinated Web 2.0 tools. A high level of social norms for the supply chain partners can positively influence the information sharing (Chiu et al., undated) which in turn influences mitigating bullwhip effect (Lee \& Whang, 2000). To reduce bullwhip effect, suppliers try to get the real-time market information through brand visibility (Lin, Chiu, \& Wu, 2013). Therefore, the use of Web 2.0 and other Mash-Up techniques help in creating real-time market information (Cooke \& Buckley, 2008). Thus,

H2: There is a significant positive contributory relationship between using the Social Media Monitoring software and reduction in Bullwhip Effect in Supply Chain.

\subsection{Influence of BI on Mitigating Bullwhip Effect}

Multi-dimensional deep-dive web analytics can optimize marketing efforts with: (i) geo-profiling insights, (ii) search engine analytics, (iii) internal search analysis, (iv) user behaviour insights, (v) social media influencers, (vi) and customer segmentation (AlSudairi et al., 2012). Web Intelligence when combined with Business Intelligence (BI) can provide campaign optimization intelligence and site optimization intelligence. Once entered into the domain of BI, rooted in rigorous scientific methodologies, BI provides on-demand conversion of real time sampling of attitudinal and likely behaviour data into validated insights as a part of predictive intelligence so that managers peer into the future with increased certainty. It uses advanced analytics and visualization tools for this purpose. Web-based predictive intelligence systems are able to reach out and collect accurate data from areas once obscured by their separation from the business. Applying the concepts of BI to data from SCM systems, supply chain analytics seek to provide strategic information to decision makers in organizations. BI has a potential to provide essential valuable interpretation based information regarding not only the customer service delivery time and cost derived from downstream supply chain to upstream supply chain using analytical eCRM techniques, but also to solve strategic business problem brining visibility to key supply chain processes with supply chain intelligence (AlSudairi et al., 2012).

The optimal supply chain is built around the needs of the end customer. The perfect supply chain includes only those activities that the end customer values and is willing to pay for. This requires developing an accurate supply chain intelligence capability. The measurement of the effectiveness of supply and demand balance within a firm is probably best represented by the supply chain operations reference model (SCOR). The SCOR model reveals the capability of developing supply chain metrics such as demand intelligence, logistic intelligence, demand/supply alignment, product intelligence and supply intelligence can be achieved through applying Data Warehousing and Data Mining Techniques over Social CRM and Other external data such as SMM data (Haydock, 2003).

AlSudairi et al. (2012) posit that use of BI software in analyzing the SMM capability can positively influence the bullwhip effect in a unique way. Thus, actionable customer insights can be developed using web analytics, social media monitoring, customer/business feedback through new web site and online communities and web content/text mining and analysis. Web 2.0 in the form of eCRM 2.0 aims at exploiting both the networking and social/customer intelligence of web 2.0 by integrating and engaging customers and communities along firm's value chain operations (AlSudairi et al., 2012) and further helps in mitigating the bullwhip effect.

World class BI environment allows retailers to increase their visibility into inventory management without hampering daily operations. By extracting information from disparate source systems into a centralized repository such as an enterprise data warehouse retailers are concurrently reporting on metrics related to their supply chain, sales, production and internal operations to make better fact based business decisions. By utilizing Data Warehousing that supports trending on both historical and future data metrics such as weeks of supply, sell-through, inventory turnover gross margin return on inventory and shrinkage, retailers can improve information quality and accuracy, manage inventory level to avoid lost sales or over supply, provide external vendors with increased visibility into product performance and allow managers and executives to make more timely decision using a common set of data trusted across the entire user community (Algara \& Charen, 2008). Supply Chain control dashboards when combined with electronic solutions and data calculation capability can help in improving operative decisions in supplychain (Dreyer et al., 2009) and reduces bullwhip effect (Kim \& Lm, 2002). 
H3: There is a significant positive contributory relationship between using the Business Intelligence software and reduction in Bullwhip Effect in Supply Chain.

\section{Research Method}

A research study is employed to test the hypothesis based on a simple random sample collection of the required data. The population study consists of IT departments at manufacturing \& process industries, retail, transportation/logistics, and wholesaler/distributor in Saudi Arabia and Jordan. The data collected through a pre-designed questionnaire which was directed to the marketing people. The questionnaire is validated by academicians and experts. Their opinions and comments are considered while designing the questionnaire. Based on following the IDG Research suggestions, and based on the self-administered questionnaire, a survey is conducted for studying 300 qualified responses. Furthermore, participants received an email message inviting them to participate in the survey. Each participant receives a unique URL link to access the survey. The research Construct Operationalization is explained in Table 1.

Table 1. Research construct operationalization

\begin{tabular}{|c|c|}
\hline Research Construct & Author (s) \\
\hline I. $\quad$ ERP software (ERP1-ERP4) & Deloitte Consulting (1999), Laughlin (1999), Stenbeck, \\
\hline Employing ERP software will lead to: & 1998) \\
\hline ERP1: Reduction in inventory levels & $\begin{array}{l}\text { Elragal \& Al-Serafi (2011); Tsai (2011); Mandal \& } \\
\text { Gunasekaran, (2002); Lee, Padmanabhan \& Whang } \\
\text { (1997); Lee, So \& Tang, (2000) }\end{array}$ \\
\hline ERP2: Reduction in time delays & $\begin{array}{l}\text { McCullen and Towill(2002); Disney and Towill (2003a); } \\
\text { Disney \& Towill(2003b); Ravichandran (2008) }\end{array}$ \\
\hline ERP3: Improvements in order management and cycle times & $\begin{array}{l}\text { Kelle, Akbulut (2005); Ravichandran (2008); Tarantilis, } \\
\text { Kiranoudis \& Theodorakopoulos (2008) }\end{array}$ \\
\hline ERP4: Reduction in procurement costs & Baudmann, Ahsen \& Diaz (2004) \\
\hline $\begin{array}{l}\text { II. Social Media Monitoring software (SMM1-SMM4) } \\
\text { SMM1: We use social media sites to interact with our supply chain } \\
\text { transactions/vendors/partners in the form of e-Word-of-Mouth }\end{array}$ & $\begin{array}{l}\text { IDG \& Kemp GoldBerg (2011) } \\
\text { AlSudairi et al. (2012) }\end{array}$ \\
\hline $\begin{array}{l}\text { SMM2: We are aware of our primary supply chain vendors/partners usage of } \\
\text { social media sites or services in the form of Communicating the relevant } \\
\text { information }\end{array}$ & Auinger \& Nedbal (2009) \\
\hline $\begin{array}{l}\text { SMM3: Our supply chain transactions/vendors/partners are likely to use social } \\
\text { media sites to provide visibility of their real time market information through } \\
\text { their brand presence and product promotions }\end{array}$ & Lin, Chiu \& Wu (Undated); Cooke and Nick (2008) \\
\hline $\begin{array}{l}\text { SMM4: Our supply chain transactions/vendors/partners find that there is Business } \\
\text { value exists by following any social media software }\end{array}$ & IDG \& Kemp GoldBerg (2011) \\
\hline $\begin{array}{l}\text { III. Business Intelligence Software (BISI-BIS3)contributes positively in } \\
\text { reducing Bullwhip Effect }\end{array}$ & Elbashir, Collier and Davern (2008) \\
\hline BIS1: Web based Predictive Intelligence Capability can reduce variability & AlSudairi et al. (2012) \\
\hline $\begin{array}{l}\text { BIS2: BI software allows integrating and engaging customers and communities } \\
\text { along firm's value chain operations to reduce uncertainty }\end{array}$ & Algara \& Charen (2008). \\
\hline $\begin{array}{l}\text { BIS3: BI Software improves information quality and accuracy in quantitative } \\
\text { aspect to help intime-to-market decision }\end{array}$ & Algara \& Charen (2008). \\
\hline Reduction in Bullwhip Effect (RBE1-RBE3): & Simchi-Levi et al. (2000) \\
\hline Using ERP, SMM, and BIS will & \\
\hline RBE1: reduce uncertainty & Simchi-Levi et al. (2000) \\
\hline RBE2: reduce variability & Simchi-Levi et al. (2000) \\
\hline RBE3: reduce lead-time & Simchi-Levi et al. (2000) \\
\hline
\end{tabular}

\section{Results}

\section{Exploratory Factor Analysis}

The analysis started by examining the structure and dimensionality of the study constructs using exploratory factor analysis (EFA) and reliability analysis. After examining the pattern matrix of the EFA, all items had 
loadings greater than 0.4 and communalities greater than 0.5 .

\subsection{Measurement Model}

We evaluated the measurement and structural equation models using SPSS AMOS. The measurement model includes 14 indicators, and we provide its results in Table 2 including the standardized factor loading, standard error (SE), t-values, and average variance extracted (AVE). The standardized factor loadings $(\lambda)$ are all greater than .6. The composite reliabilities for ERP (0.92), SSM (0.92), BIS (0.92), and BRE (0.87) are all within the acceptable range (Hair et al., 1998). Moreover, AVE by each construct exceeds the minimum value ( 0.5 or above) recommended by Hair et al. (1998), indicating convergent validity. The square roots of the average variance extracted by each construct exceed the correlation between them (Table 3), demonstrating discriminant validity. Thus, our instrument had satisfactory construct validity (Anderson \& Gerbing, 1988; Fornell \& Larcker, 1981). Further, we used a battery of fit indexes $\left(\chi^{2}=200.250, \mathrm{df}=70\right.$; and $\left.\chi^{2} / \mathrm{df}=2.86\right)$ comparative fit index [CFI] $=.924$; goodness-of-fit index $[\mathrm{GFI}]=.924$; Tucker-Lewis index $[\mathrm{TLI}]=.921$; incremental fit index $[\mathrm{IFI}]=.907$; root mean square error of approximation $[$ RMSEA] $=.0601)$ to measure the validity of the proposed model, which all are acceptable (Byrne, 2001; Hair et al., 1998).

Table 2. Measurement model summary

\begin{tabular}{|c|c|c|c|c|c|}
\hline Construct & $\begin{array}{l}\text { Standardised factor } \\
\text { loading }(\lambda)\end{array}$ & SE & t-value & $\begin{array}{l}\text { Discriminant } \\
\text { validity (AVE) }\end{array}$ & $\begin{array}{l}\text { Composite } \\
\text { reliability }\end{array}$ \\
\hline$\eta 1$ (Core ERP software) & & & & .73 & .92 \\
\hline ERP1 & .882 & - & & & \\
\hline ERP2 & .807 & .131 & 5.375 & & \\
\hline ERP3 & .837 & .133 & 5.225 & & \\
\hline ERP4 & .891 & .100 & 4.458 & & \\
\hline ๆ2 (Social Media Monitoring) & & & & .74 & .92 \\
\hline SMM1 & .801 & - & & & \\
\hline SMM2 & .859 & .111 & 12.818 & & \\
\hline SMM3 & .888 & .187 & 6.929 & & \\
\hline SMM4 & .893 & .219 & 7.346 & & \\
\hline$\eta 3$ (Business Intelligence Software) & & & & .79 & .92 \\
\hline BIS1 & .966 & - & & & \\
\hline BIS2 & .838 & .116 & 9.582 & & \\
\hline BIS3 & .852 & .189 & 5.606 & & \\
\hline$\eta 4$ (Reduction in Bullwhip Effect) & & & & .69 & .87 \\
\hline RBE 1 & .835 & - & & & \\
\hline RBE 2 & .853 & .059 & 19.361 & & \\
\hline RBE 3 & .798 & .097 & 12.057 & & \\
\hline
\end{tabular}

Table 3. Correlation coefficients and discriminant validity

\begin{tabular}{llll}
\hline Model Constructs & Mitigating Bullwhip Effect & \\
\hline 1. ERP & $\mathbf{. 8 5}$ & & \\
2. SMM & .224 & $\mathbf{. 8 6}$ & $\mathbf{. 8 9}$ \\
3. BIS & .331 & .220 & .265 \\
4. RBE & .254 & .124 & $\mathbf{. 8 3}$ \\
\hline
\end{tabular}

The figures under the diagonal are the Pearson (R) correlations between the variables. Diagonal elements are square roots of average variance extracted. 


\subsection{Structural Equation Model}

The structural equation model confirms that ERP, SMM and BIS have significant positive effects on BRE $\left(\mathrm{H}_{1} \mathrm{t}=\right.$, $\beta=.28, p<0.001)$, SMM $\left(\mathrm{H}_{2} \mathrm{t}=, \beta=.27, p<0.001\right)$, BIS $\left(\mathrm{H}_{13} \mathrm{t}=, \beta=.40, p<0.001\right)$. Finally, coefficient of determination $\left(\mathrm{R}^{2}\right)$ for reduction in bullwhip effect $=0.58$.

\section{Discussions}

This research aims to investigate the impact of utilizing enterprise level marketing information systems on the reduction of bullwhip effect. We adopted a combination of software tools; ERP software, Social Media Monitoring Tools, Business Intelligence Tools to study the impact. We found that utilizing ERP software often helps organizations to mitigate the bullwhip effect resulting from information distortion to upstream firms of supply chain. This result comes in accordance with previous research (Lai, Xu \& Zhu, 2010; Ravichandran, 2006; Burns \& Janamanchi, 2006; Nieuwenhuyse et al., 2011). Utilizing ERP software often reduces inventory levels, improve business performance via reducing number of employees, and reduce the time and information delays. All the above will have a positive impact on mitigating the bullwhip effect which often enhance supply chain effectiveness.

Furthermore, utilizing SMM tools, to interact with supply chain transactions, to monitor the information related to business, product competition, key words, phrases and results categorized by the type of social medium such as tweet, blog, post, forum, news item, video or image ensure that relevant information is available through the use of Web 2.0 technologies to stem the bullwhip effect. Social Media engagement strategy can be achieved by developing, implementing an integrated and coordinated Web 2.0 tools. Utilizing SMM for the supply chain partners can positively influence the information sharing which is expected to influences mitigating bullwhip effect.

Moreover, utilizing BI software provides on-demand conversion of real time sampling which reduce; customer return handling costs, marketing costs, and time to market product or services. Further, BI has a potential to provide proper information which help the customer service delivery time and cost derived from downstream supply chain to upstream supply chain using analytical eCRM techniques but also to solve strategic business problem brining visibility to key supply chain processes with Supply Chain Intelligence (AlSudairi et al., 2012). Thus, use of BI software positively influences the reduction of bullwhip effect in a unique way. Therefore it can improve information quality and accuracy.

\section{Managerial Implication}

In a modern society where internet usage is increasing, organizations must rely on the importance of employing enterprise marketing information system in the form of ERP software, SMM Tools and BI Tools which often reduce the bullwhip effect. Therefore, we encourage organisations to use the above tools in order to; (i) ensure that all levels of the supply chain have visibility to final demand, (ii) reduce the time and information delays, (iii) improve order management, cycle times and reduce procurement costs, (iiii) influences the information sharing and gets the real-time market information.

\section{Limitations}

We admit the following limitations. First, we did not include particular SMM tools in our study such as the impact of Facebook, or Twitter on reducing the bullwhip effect. Therefore, we invite other researchers to investigate this issue. Second, while conducting this research we did not measure the impact of the software on organization size. Future research should investigate the impact of organization size as a moderator on the proposed relationships. Third, generalizability of our study could be limited to the environment which we conducted this research on (non-western context), further research are welcome to apply this study on a western-context.

\section{References}

Achrol, R. S., \& Kotler, P. (1999). Marketing in the Network Economy, Journal of Marketing, 63, 146-163.

Agarwal, S., Sengupta, R. N., \& Shanker, K. (2009). Impact of information sharing and lead time on bullwhip effect and on-hand inventory. European Journal of Operational Research, 192(2), 576-593. http://dx.doi.org/10.1016/j.ejor.2007.09.015

Akkermans, H. A., Bogerd, P., Yucesan, E., \& Van Wassenhove, L. N. (2003). The impact of ERP on supply chain management: Exploratory findings from a European Delphi study. European Journal of Operational Research, 146, 248-301. http://dx.doi.org/10.1016/S0377-2217(02)00550-7

Algara, \& Charen. (2008). 5 ways business intelligence can enhance inventory management. Retrieved from 
http://www.claraview.com/resource-center/white-papers-articles/5-ways-business-intelligence-can-enhanceinventory-management

Algharabat, \& Zamil. (2013). The Impact of Retail Store Global-Mindedness on Jordanian Consumers' Patronage Intention. International Journal of Marketing Studies, 5(4), 30-41. http://dx.doi.org/10.5539/ijms.v5n4p30

Al-Shaikh, M. S. (2010). The Effect of Marketing Information System on Decision Making. Recherches économiques et managerials, $\mathrm{N}^{\circ} 7$.

Anderson, J. C., \& Gerbing, D. W. (1988). Structural Equation Modeling in Practice: A Review and Recommended Two-Step Approach. Psychological Bulletin, 103(3), 411-423. http://dx.doi.org/10.1037/0033-2909.103.3.411

Aral, S., Brynjolfsson, E., \& Wu, D. J. (2005). Does Process Enabling IT Matter? Measuring the Business Value of Extended Enterprise Systems, WISE 2005. Retrieved on September 5, 2012, from http://web.merage.uci.edu/ veecee/WISE2005/papers/165.pdf

Auinger, A., \& Nedbal, D. (2009). Effective supply chain information management in supply networks using Enterprise 2.0. Retrieved on September 5, 2012, from http://research.fh-ooe.at/files/publications/1103_09_EEE_SCIM20_publiziert.pdf

Badillo-Pina, I., Tejeida-Padilla, R., \& Morales-Matamoros, O. (2012). A Systems Science Perspective for Supply chain Management. Retrieved on April 3, 2013, from http://journals.isss.org/index.php/proceedings56th/article/viewFile/1766/611

Barid, C. H., \& Parasnis, G. (2011). From social media to social CRM: reinventing the customer relationship. Strategy \& Leadership, 39(6), 27-34. http://dx.doi.org/10.1108/10878571111176600

Baudmann, A., \& Diaz. (2004). Usage and evaluation of Supply Chain Management Software -results of an empirical study in the European automotive industry. Wiley Online Library.

Bihr, P. (2010). In Social Media, ROI (Return on Interaction and Return on Influence). Retrived from http://www.thewavingcat.com/2010/06/02/2854/

Bullwhip Effect. (2012). Bullwhip Effect-a lesson for SCM partners to be fair. A comprehensive guide on Materials \& Supply Chain Management. Retrieved on September 5, 2012, from http://www.supplychainmanagement.in/supply-chain-management/bullwhip-effect-in-supply-chain.htm

Burns, J. R., \& Janamanchi, B. (2006). Strategies for Reducing Inventory Costs and Mitigating the Bullwhip Effect in Supply Chain: A Simulation Study. Proceedings of the SWDSI Annual Conferences, 598-607

Byrne, B. (2001). Structural Equation Modeling with AMOS. Lawrence Erlbaum Associate.

Cachon, G. P., Taylor, R., \& Glenn, M. S. (2007). In Search of the Bullwhip Effect, Manufacturing and Service Operations Management, 9(4), 457-479. http://dx.doi.org/10.1287/msom.1060.0149

Casals, L., Davis, M., \& Nemet, G. (2001). Supply Chain Responses in a Consumer-Centric Market Place. Institute For The Future, SR 734, Peppers and Rogers Group. Retrieved on September 5, 2012, from http://www.iftf.org/system/files/deliverables/SR-734_Supply_Chain_Responses.pdf

Charles, V., Trappey, A., \& Trappey, J. C. (1998). A chain store marketing information system: realizing Internet-based enterprise integration and electronic commerce. Industrial Management \& Data Systems, 98(5), 205-213. 10.1108/02635579810227733

Chen, F. (2005). Information sharing and supply chain coordination. In A. G. De Kok \& S. C. Graves (Eds.), Handbooks in Operations Research and Management Science (Vol. 11). Supply Chain Management: Design, Coordination, and Operation, Elsevier, Amsterdam.

Cheung, C. M. K., Lee, M. K. O., \& Rabjohn, N. (2008). The impact of electronic word-of-mouth: The adoption of online opinions in online customer communities. Internet Research, 18(3), 229-247. http://dx.doi.org/10.1108/10662240810883290

Chiu et al. (2013). How Social Capital Achieves Information Sharing Effectiveness with Supply Chain. Retrieved from http://www.isu.edu.tw/upload/28/3/29520/paper/9704/970405.pdf

Cooke, M., \& Nick B. (2008). Web 2.0, social networks and the future of market research. International Journal of Market Research, 50(2), 267.

Deloitte Consulting. (1999). ERP's second wave: maximizing the value of ERP-enabled processes. Retrieved 
from http://www.deloitte.com/publications/m0499_1.html

Disney, S. M., \& Towill, D. R. (2003a). Vendor-managed inventory and bullwhip reduction in a two-level supply chain. International Journal of Operations \& Production Management, 23(6), 625-651. http://dx.doi.org/10.1108/01443570310476654

Disney, S. M., \& Towill, D. R. (2003b). The effect of vendor managed inventory (VMI) dynamics on the Bullwhip Effect in supply chains. International Journal of Production Economics, 85(2), 199-215. http://dx.doi.org/10.1016/S0925-5273(03)00110-5

Dreyer, H. C., Alfnes, E., Standhagen, J. O., \& Thomassen, M. K. (2009). Global Supply Chain control systems: a conceptual framework for the global control centre, Production Planning \& Control. The Management of Operations, 20(2), 147-157. http://dx.doi.org/10.1080/09537280802705013

Elbashir, C. D. (2008). Measuring the effects of business intelligence systems:The relationship between business process and organizational performance. International Journal of Accounting Information Systems, 9, 135-153. http://dx.doi.org/10.1016/j.accinf.2008.03.001

Elragal, A. A., \& Al-Serafi, A. M. (2011). The Effect of ERP System Implementation on Business Performance: An Exploratory Case-Study (12\&14) Communications of the IBIMA. Retrieved from http://www.ibimapublishing.com/journals/CIBIMA/cibima.html

Fornell, C., \&Larcker, D. F. (1981). Evaluating structural equation models with unobservable variables and measurement error. Journal of Marketing Research, 18(1), 39-50. Retrieved from http://www.jstor.org/stable/3151312

Fransoo J. C., Wouters M. J. F. (2000). Measuring the bullwhip effect in the supply chain. Supply Chain Management: An International Journal, 5(2), 78-89. http://dx.doi.org/10.1108/13598540010319993

Glazer, R. (1991). Marketing in an Information-Intensive Environment: Strategic Implications of Knowledge as an Asset. Journal of Marketing, 55(4), 1-19. Retrieved from http://www.jstor.org/stable/1251953

Greis, N. P., \& Kasarda, J. D. (1997). Enterprise Logistics in the Information Era. California Management Review, 39(4).

Hair, J., Anderson, R., Tatham, R., \& Black, W. (1998). Multivariate Data Analysis. Prentice-Hall, Upper Saddle River, NJ. New Jersey, U.S.A

Haydock, M. P. (2003). Supply chain intelligence. Achieving Supply Chain Excellence Through Technology, 5, $15-21$.

Hendricks, K. B., Snghal, V. R., \& Stratman, J. K. (2007). The impact of enterprise systems on corporate performance: A study of ERP, SCM and CRM system implementations. Journal of Operations Management, 25, 65-82. http://dx.doi.org/10.1016/j.jom.2006.02.002

IDG. \& Kemp, G. (2011). Research Study: Social CRM in the Supply Chain. Retrieved on September 8, 2012 from http://www.kempgoldberg.com/wp-content/themes/kg_/images/IDG_KGP_Survey_Results.pdf

Ismail, S. T. (2011). The Role of Marketing Information System on Decision Making An Applied study on Royal Jordanian Air Lines (RJA). International Journal of Business and Social Science, 2(3).

Kelle, P., \& Akbulut, A. (2005). The role of ERP tools in supply chain information sharing, cooperation and cost optimization. International Journal of Production Economics, 94(8), 41-52. http://dx.doi.org/10.1016/j.ijpe.2004.06.004

Kim, K. C., \& Im, I. (2002). The effects of electronic supply chain design (e-SCD) on coordination and knowledge sharing: An empirical investigation. In System Sciences, 2002. HICSS. Proceedings of the 35th Annual Hawaii International Conference on (pp. 2149-2158). IEEE.

Kopczak, L. R., \& Johnson, M. E. (2003). The supply-chain management effect. MIT Sloan Management Review, 27-34.

Lai, R., Xu, S. X., \& Zhu, K. (2010). How does Information Technology Affect Inventory? The Role of Moderators and Mediators. In H. Zhang (Ed.), Proceedings of the Forth China Summer Workshop on Information Management. Wuhan, China.

Laughlin., S. P. (1999). An ERP game plan. Journal of Business Strategy, 20(1), 32-37.

Lee, H. L., \& Whang, S. (2000). Information Sharing in a Supply Chain. International Journal of Manufacturing Technology and Management, 1(1), 79-93. 
Lee, H. L., Padmanabhan, V., \& Whang, S. W. (1997b). The Bullwhip Effect in Supply Chains. Sloan Management Review, 38(3), 93-102.

Lee, H. L., So, K. C., \& Tang, C. S. (2000). The value of information sharing in a two level supply chain. Management Science, 46(5), 626-643. http://dx.doi.org/10.1287/mnsc.46.5.626.12047

Lee, H., Padmanabhan, P., \& Whang, S. (1997a). Information Distortion in a Supply Chain: The Bullwhip Effect. Management Science, 43(4), 546-558. http://dx.doi.org/10.1287/mnsc.43.4.546

Lin, C. W. (2013). The development strategy of supplier in supply chain. Retrieved on April 6, 2013, https://www.ntpu.edu.tw/admin/a14/orda/ads/www/doc/96/11-1.pdf

Lummus, R. R., Duclos, L. K., \& Vokurka, R. J. (2003). The impact of marketing initiatives on the supply chain. Supply Chain Management: An International Journal, 8(4), 317-323. http://dx.doi.org/10.1108/13598540310490071

Mandal, P., \& Gunasekaran, A. (2002). Application of SAP R/3 in on-line inventory control. International Journal of Production Economics, 75, 47-55. http://dx.doi.org/10.1016/S0925-5273(01)00180-3

Matloub, H., \& Paul, R. D. (2011). Analysis of the bullwhip effect with order batching in multi-echelon supply chains. International Journal of Physical Distribution \& Logistics Management, 41(10), 972-990. http://dx.doi.org/10.1108/09600031111166438

McCullen, P., \& Towill, D. (2002). Diagnosis and reduction of bullwhip in supply chains. Supply Chain Management: An International Journal, 7(3), 164-179. http://dx.doi.org/10.1108/13598540210436612

Moinzadeh, K. (2002). A multi-echelon inventory system with information exchange. Management Science, 48(3), 414-426. http://dx.doi.org/10.1287/mnsc.48.3.414.7730

Moller, C. (2005). ERP II: A conceptual framework for next-generation enterprise systems? Journal of Enterprise Information Management, 18(4), 483-497. http://dx.doi.org/10.1108/17410390510609626

Moyaux, T., Chaib-draa, B., \& D'Amours, S. (2007). Information Sharing as a Coordination Mechanism for Reducing the Bullwhip Effect in a Supply Chain. IEEE Transactions on Systems, Man, and Cybernetics, 37(3), 396-409. http://dx.doi.org/10.1109/TSMCC.2006.887014

Nieuwenhuyse, I. V. (2011). Advanced resource planning as a decision support module for ERP. Computers in Industry, 62, 1-8. http://dx.doi.org/10.1016/j.compind.2010.05.017

Parvathiyar, A., \& Seth, J. N. (2001). Customer Relationship Management: Emerging Practice, Process and Discipline. Journal of Economic and Social Research, 3(2), 1-34.

Prahlad, \& Ramaswamy. (2004). Co-creation Experiences: The next practice in value creation. Journal of Interactive Marketing, 18(3), 5-14. http://dx.doi.org/10.1002/dir.20015

Ravichandran, N. (2006). Managing Bullwhip Effect: Two Case Studies. Research and Publications Series: Indian Institute of Management, Ahmedabad. Retrieved from http://www.iimahd.ernet.in/publications/data/2006-08--01nravichandran.pdf

Ravichandran, N. (2008). Managing bullwhip effect: Two case studies. Journal of Advances in Management Research, 5(2), 77-87.

Simchi-Levi, D., Kaminsky, P., Simchi-Levi, E. (2000). Designing and Managing the Supply Chain. McGraw-Hill, printed in Singapore.

Stenbeck, J. (1998). Quantum leap forward. Retrieved from http://www.lionhrtpub.com/ee/ee-summer98/quantum.html

Tarantilis, C. D., Kiranoudis, C. T., \& Thodorakopoulos, N. D. (2008). A Web-based ERP system for business services and supply chain management: Application to real-world process scheduling. European Journal of Operational Research, 187(3), 1310-1326. http://dx.doi.org/10.1016/j.ejor.2006.09.015

Torres, \& Maltz. (2010). Understanding the financial consequences of the Bullwhip effect in a multi-echelon $\begin{array}{lllll}\text { supply chain. Journal of } & \text { Business }\end{array}$ http://dx.doi.org/10.1002/j.2158-1592.2010.tb00126.x

Tsai, B. (2011). Exploring the influence of enterprise resource planning (ERP) implementation corporate performance using a modified data envelopment analysis (DEA) approach. African Journal of Business Management, 5(14), 5435-5448. http://dx.doi.org/10.5897/AJBM10.809 
Yu, Z., Yan, H., \& Cheng, T. C. E. (2001). Benefits of information sharing with supply chain partnerships. Industrial Management \& Data Systems, 101(3), 114-121. http://dx.doi.org/10.1108/02635570110386625

\section{Copyrights}

Copyright for this article is retained by the author(s), with first publication rights granted to the journal.

This is an open-access article distributed under the terms and conditions of the Creative Commons Attribution license (http://creativecommons.org/licenses/by/3.0/). 